\title{
ESL STUDENT REACTION TO WRITTEN COMMENTS ON THEIR WRITTEN WORK
}

\author{
PATRICIA M. RADECKI and JOHN M. SWALES
}

\author{
The University of Michigan, Ann Arbor, USA
}

\begin{abstract}
Although studies of instructor response to student writing are numerous in both $\mathrm{Ll}$ and L2 contexts, the literature on student reaction to those comments is small in L2 research. Partly for this reason, we have examined ESL students' own preferences and views on feedback. We surveyed the attitudes of 59 students in four ESL-oriented classes. Our questionnaire elicited their opinions on the usefulness of various types of comments, the scope of teacher markings, responsibility in error marking and correction, and revision. Eight students were then selected for interview (either audio- or video-taped). The respondents can be divided into three categories, primarily according to their degrees of acceptance of revision and of teacher intervention in providing input: Receptors (46\%), Semi-resistors $(41 \%)$, and Resistors (13\%). The survey revealed that as students progress from English language learners to apprentices in their chosen discipline, the more restricted is the role they assign to the language teacher.
\end{abstract}

\section{INTRODUCTION}

In ESL, learner training has been largely associated with communicative or task-based approaches, an example being the preparation of students to work effectively in small groups. Although the concept of learner training has been less clearly articulated in ESL composition, there already exists interest in a range of pre-writing activities such as invention techniques. Such activities, however, are more cognitive than affective and thus do not bear upon the important issue of student attitudes and expectations upon entry to a writing course; nor do they address the question of how particular attitudes might affect writing behaviour. Therefore, gaining information about students' attitudes to writing, and about the roles they assign to themselves and to their instructor in the review process, would be of value in devising courses that take into account these attitudes. With such a purpose in mind, we surveyed the feedback views of 59 ESL students of various backgrounds and levels at the University of Michigan. In addition, we interviewed eight of the respondents to obtain more detailed information about their attitudes.

A further reason for our interest in this aspect of ESL composition is the apparent paucity of work in this area. There have been several studies of L1 students' reactions to instructor comment, but only one (Cohen, forthcoming) that to our knowledge has dealt with ESL student reactions. Thus it is useful for the L2 researcher to consider the L1 literature, especially with regard to methodology and approach. It would also seem reasonable to relate the student reaction studies to research on the actual effects of written comments on subsequent student writing. In turn, the latter studies are contingent on the types of response that instructors have provided. Therefore, 
the following brief survey begins with a review of research on instructor response and its actual effects on student writing, and then turns to research on student feedback preferences.

In the analysis of $\mathrm{L} 1$ instructor response, the researchers have generally called into question the markings they found, assessing them as ineffectual in facilitating revision, that is, in causing changes in the content or macrostructure of a piece of writing (Faigley and iWitte, 1981). Comments analyzed by Schwartz (1984), Siegel (1982), and Sommers (1982) were described as conflicting, vague, prescriptive, and easily applicable across student texts. ' Ziv's study (1984) has provided some evidence that the type of comments found by Sommers and others have negligible effects on student writing. Ziv compared the effects of "explicit" (explanatory and content-specific) with "implicit" (prescriptive or corrective) markings on revisions. The students in her study responded to the explicit rather than implicit comments of their instructor in their revised papers.

The major study we located on the nature of instructor response to L2 writing concurs with the findings of the L1 studies. Zamel (1985) found that most of the comments of her $15 \mathrm{ESL}$ instructors on 105 learner essays dealt with sentence-level concerns. She also discovered that when the instructors attempted to advise students on how to revise their essays, their comments were abstract or prescriptive, and rarely referred directly to the content of the essay.

The research on the actual effects of instructor feedback on L2 writing has been limited to comparing the effects of different types of treatment of sentence-level errors, and thus it indirectly supports Zamel's contention that ESL instructors are concerned mostly with mechanics. Studies undertaken by Hendrickson (1976, 1977), Lalande (1982), Semke (1984) and Robb et al. (1986) have shown the questionable value of instructor correction of all or some of the mechanical and linguistic errors in a piece of writing. ${ }^{2}$

The research most related to the topic of this paper, college-level student attitudes to written feedback, has thus far been concentrated in L1 contexts (e.g. Lynch and Klemens, 1978; Reed and Burton, 1981; and Burkland and Grimm, 1984). Most of the students surveyed wanted their instructors to attend to mechanical errors. The students interviewed by Lynch and Klemens (1978) found those types of comments most useful. On the other hand, students in all three surveys expressed a preference for comments or criticisms that did not merely locate problems but which were explicit according to $\mathrm{Ziv}$ (1984).

The only study known to us that incorporates the reactions of L2 students is that of Cohen (forthcoming). In his survey of $34 \mathrm{ESL}, 60 \mathrm{L1}$, and $123 \mathrm{FL}$ college-level students, the students were asked to describe the comments they received and to reveal how they utilized instructor comments. The most popular response to the latter was "to make a mental note". Thus, the results of this survey also support Zamel's findings (1985), as $83 \%$ of the respondents reported that their teachers commented mostly on grammar.

The above research shows, then, that students in both the $\mathrm{L} 1$ and $\mathrm{L} 2$ domains prefer the types of comments that have been shown to be ineffectual in improving writing. As it shall be seen, some of our respondents conformed to these findings, while others did not. 


\section{QUESTIONNAIRE PROCEDURE}

In the first stage of our study, 59 ESL students were surveyed by questionnaire. The students were from one of four ESL-oriented writing courses as listed in Table 1.

Table 1. Distribution of students surveyed

\begin{tabular}{lcl}
\hline Course name & $\begin{array}{c}\text { No. of } \\
\text { students }\end{array}$ & Fotes non-enrolled students \\
\hline ELI Upper Level Writing & 12 & $\begin{array}{l}\text { An Introductory Composition section for } \\
\text { non-native speakers }\end{array}$ \\
English 125 & 10 & $\begin{array}{l}\text { A class in academic writing for enrolled } \\
\text { ESL students (mostly graduate level) }\end{array}$ \\
Humanities 610 & 24 & $\begin{array}{l}\text { A section of advanced technical writing } \\
\text { for ESL engineering graduate students }\end{array}$ \\
\hline
\end{tabular}

The students completed the 18-item questionnaire during the first week of classes, before they had received much input from their instructors. The questionnaire evoked students'attitudes to teacher comment, correction and instruction. It also elicited their opinions on the usefulness of various types of comments. For example, we investigated their views on the scope of teacher commenting and also whether they valued and utilized substantive comments. We also asked them for their views on responsibility in error marking and correction and on rewriting. Lastly, the questionnaire elicited their assumptions about their instructor's expectations concerning their utilization of the feedback provided.

\section{QUESTIONNAIRE RESULTS}

Responses to the questionnaire revealed a great measure of consensus. Most of the students reported positive or at least neutral reactions upon receiving a heavily marked paper whatever the nature of the markings. They declared that they would read the comments and even expressed satisfaction that their teacher had marked their papers: "I feel comfortable to know my mistakes to correct them". Most of the students also reported that they look first at the grade on their returned paper rather than the comments, implying that initially the grade is of more concern to them. Most students, as well, expressed approval for marking symbols. Furthermore, nearly all students revealed that they review their corrected work only one or two times, immediately upon receiving it or before a test or examination. Finally, a majority of students felt they could approach their instructor to dispute what they perceived as an invalid comment or marking.

More significant and prevalent than the commonalities were the differences. Consequently we placed the students into three categories: Receptors (46\%), Semi-resistors (41\%), and Resistors $(13 \%)$. The three types are distinguished from one another in terms of their attitude towards different types of comments, the marking and correcting of grammatical errors, the domain of teacher intervention, and revision. They also differed in their sensitivity to their writing instructor's 
expectations. Before we discuss the distribution of student types across the three categories, we will first describe in greater detail the attitudinal characteristics of the groups.

In terms of marking preferences, both Receptors and Semi-resistors preferred substantive comments, or comments that were content-specific, but also appreciated one-word judgements. Receptors in particular wanted instructors to respond to the content of their essays in terms of both the quality of their ideas and the accuracy of their facts.

Also, Receptors and Semi-resistors overwhelmingly desired to have all their linguistic errors marked, their response suggesting that error marking was a major responsibility of the teacher. In contrast, the Resistor minority preferred short evaluative adjectives and a grade, or a grade alone. For instance, the Resistors tended to respond to the question "What's your reaction to a paper with only a grade on it?" with a stoical comment such as "I don't mind". Only half of the Resistors wanted even their serious errors identified for them.

As for correction of linguistic errors, the Receptors felt that a joint responsibility between instructor and student was in order. Many said that the student should try to correct mistakes, and those the student could not should then be corrected by the teacher. The responses of the Semi-resistors varied according to their course level. The majority of Resistors felt it was the teacher's job to correct errors. This finding, though, is somewhat anomalous with the Resistors' desire to have all errors marked. It seems that Resistors will forego substantive comments and want only their most serious errors marked, but want all those errors to be rectified by their instructor.

The responses to rewriting formed a clear cut and major distinction among the student categories. Receptors would gladly rewrite their essays if their teachers advised them to do so, although graduate students required sufficient justification from their instructor. In contrast to the Receptors, both Semi-resistors and Resistors expressed reluctance or hostility toward revision. Most of them saw no redeeming value in rewriting, some viewing it as punishment: "Rewrite is only a way of penalty in elementary school. It only wastes our time. What do you say if somebody copies the paragraph in front of the T.V. set?', Their answers revealed a mistaken notion of revision as merely the correction of surface-level errors.

Finally, when asked how the teacher would feel if they ostensibly ignored feedback, both Receptors and Semi-resistors though their instructor would be disappointed or think ill of them: "She would feel that you are not bothered and not interested. That would be bad for teachers and pupil relationship". Thus the Receptors and Semi-resistors felt some obligation for utilizing teacher feedback; their comments suggested that they would experience some guilt if they did not. On the other hand, Resistors responded that they "don't know" what the teacher would think if they did not review his/her comments, their answer implying that they do not care what the teacher feels.

Above, we have established the basis on which we categorized our sample as a whole. Next we will discuss the similarities and differences between the four class groups. The percentage figures for the classes are given in Table 2.

As the table shows, English 125 students were the most receptive, and the minority of Semiresistors among them was set apart primarily by resistance to rewriting. In contrast, Linguistics 
Table 2. Distribution of student types across the four classes

\begin{tabular}{lccc}
\hline Course & Receptors & Semi-resistors & Resistors \\
\hline ELI Upper Level Course & $50 \%$ & $42 \%$ & $8 \%$ \\
Linguistics 340 & $37.5 \%$ & $37.5 \%$ & $25 \%$ \\
English 125 & $60 \%$ & $40 \%$ & $0 \%$ \\
Humanities 610 & $46 \%$ & $46 \%$ & $8 \%$ \\
Total & $46 \%$ & $41 \%$ & $13 \%$ \\
\hline
\end{tabular}

340 students - the majority of whom were graduates - were the most resistant. Even those disposed toward rewriting were unwilling to do so unless receiving very convincing reasons from their instructor. The non-receptive majority of Linguistics 340 students demanded full error correction from the teacher, but were less insistent about selective correction than Resistors in other classes. Part of the explanation for their more resistant character may lie in the particular circumstance of their course, Linguistics 340 being an additional, non-credit requirement for them. Resistancy was also a characteristic - although to a lesser extent - of Humanities 610 students. The non-Receptor majority of Humanities 610 was not open to suggestions about content or subject matter, perhaps out of a certain defensiveness.

The overall distributions for ELI Upper Level and Humanities 610 students are similar. However, the ELI class distinguishes itself from the rest as the group least willing to accept responsibility for their own linguistic errors - that is, least apt to locate and correct errors themselves, assigning that task to their teachers. This finding might seem incongruent given that their writing ability is lower than that of the other three classes, but if we take into account that non-Receptors among the ELI students rejected content-related input from their instructor, then we see that this group not surprisingly is very much concerned with surface-level, grammatical concerns. The questionnaire results also show that indifference to teacher's feelings is a marked characteristic of the non-Receptors among ELI students, perhaps because the shorter duration of the ELI courses may tend to preclude a teacher-student relationship.

\section{THE INTERVIEW FINDINGS}

Of the eight students we interviewed, five were Receptors. In this group, there was a clear recognition that writing is an important aspect of both academic performance and successful employment, plus a belief that for the non-native speaker being able to write well in English requires sustained attack and attention - indeed one student commented that he thought learning to produce effective written documents in English was "a life-long process". This group of five also believed that organization was crucial and consequently was willing to spend time on reorganizing. They generally welcomed assistance on ideas and content: "The teacher can shift the track if you are on the wrong track". Further, they expressed an understanding of what revision entails, preferring to concentrate initially on organization and later on grammatical, lexical and spelling errors. They saw themselves as having some responsibility for correcting "careless" errors and for monitoring their writing in areas where they knew they had recurrent 
problems. Finally, several of this group were able to perform a critique their own writing (i.e., "I can see there's a problem with the transition here") and to talk about the differences they perceived between the conventions of expository writing in their first language and in English.

The remaining three students, one classified as a Semi-resistor and two as Resistors, revealed attitudes of a rather different kind. Semi-resistor A, a third-year anthropology major from Korea, has been studying in the United States for nearly four years and plans to go on to graduate school. In the following excerpt from the tape he discusses his attitude to grammatical accuracy and, by implication, his view of the role of the teacher. (Note: excerpts have not been corrected for grammatical errors.)

Interviewer: You have a strong preference for the English teacher to concentrate on the structure and organization of your writing?

A: Yes

I: Is that because that's where you feel you have the most ... problems or is that because you feel that that's the more important?

A: Yes, I guess that's important ... That's why I feel that way.

I: Why do you feel it's more important?

A: Ah ... I don't know ... quite frankly I think that as a foreigner you have some kind of limitations or whatever that you can learn on a foreign language.

I: People forgive you for some mistakes, eh? Do people forgive you for some mistakes?

A: Sometimes they do and sometimes they don't.

I: That's what happens in anthropology, is it?

A: Yes, that's right yea ... but still I think that the education ... should ... put more emphasis on the way of thinking and the logic and things like that than the grammars 'cause you can always correct the grammars ... like, if I just put my thought on paper and give it to any native speakers, they can correct it.

I: Do you think you should do that? ... Give it to somebody else and say just tidy it up?

A: Eh-ha, grammatical things yes.

I: Right ... it's not reasonable for the University of Michigan to expect you to have perfect grammar?

A: Yes, that's not reasonable.

I: What happens if you wanted to go to graduate school in anthropology? ... Would they, the graduate school, say that your grammar is not good enough ... Is that unreasonable?

A: Yes, I guess that's unreasonable.

This extract reveals two things: first, A's belief that the role of the teacher is to concentrate on structure and organization to the exclusion of surface-level errors, for which he can get aid 
from any native speaker, but also the belief that non-native speaker (NNS) student holds some sort of license to make linguistic errors and some sort of lien on others to come to his rescue. This utilitarian approach may be reasonable enough under certain circumstances, such as when an NNS individual has only occasional need to write English. In this case, however, the NNS individual is planning to obtain at least two degrees from English-medium universities. Indeed, the case of student $A$ assumes a certain irony when we remember that $A$ is majoring in anthropology, a discipline that numbers among its aims the training of students to become participant-observers in the cultures they study.

The first of the two Resistors is an Iranian who recently transferred to the University of Michigan as a pre-med sophomore. At the time of interview student B had been in the United States for about 12 months. When asked how he evaluated himself as a writer, B was pessimistic, almost defeatist:

B: Normally I'm not such a good writer ... First of all, put it this way, I'm practicing for the last three years and I'm still a bad writer, everyone know that.

$\mathrm{I}: \mathrm{Mm} \ldots$ in what way do you mean ... you make mistakes in English grammar?

B: It's not in grammar but it's just, like ...

I: The organization ... the presentation?

B: Yes, I have the same problem in my own language, I'm an Iranian. I'm really a bad writer. I can't just, like, put down whatever I think on paper.

Yet interestingly, when B was commenting on his writing classes, he often showed some uncertainty as to what was going on:

I: Can you choose the topics for your assignments in this class?

B: I mean by your own? Sure I can do something.

I: I mean, are you allowed to?

B: Wait a minute ... to some extent yes ... she wants us to write a paper about describing a table; like, the object, the subject is describing a table, but whatever table you want to choose, so I don't mind doing this kind of papers because I'm taking psychology and there's lots of papers (laughs).

More importantly, B consistently rejected any type of writing instruction that made use of rhetorical models. For example, in the next extract he is objecting to a comment suggesting that his organization of a problem-solving text was ineffective:

B: And this last thing, that's the kind of thing that I don't like it much.

I: Oh, you don't like it and why is that?

B: Because, I don't know, I have to write it in this way she wanted to ... I mean, she just say it has to be in a kind of, like, problem solution format. 
I: Oh.

B: I just wrote about ...

I: I see. So you don't like this kind of comment ... that you wrote something, even if it didn't fit into exactly what she wanted.

B: Yeah, kind of.

I: So you feel like you did a page of writing, so, and you gave it to her and that should be enough.

B: I most likely want her to read my paper, my assignments, and ... just say how good I am at writing and how bad I am writing and where are my weak points and rather than just saying I'm off the track (laughs). That's it.

B offers us a paradox. On one side, he conceives of writing as the spontaneous flow of his thoughts onto the written page, conceding that what he writes lacks appropriate shape and organization. On the other side, his lack of a sense of audience and his refusal to accept that there may be merit in following standardized rhetorical models (at least for training purposes) prevent him from successfully addressing his problems in organization. It is perhaps not surprising that he does not always have a clear idea of where the writing class is going and why; moreover, it is not totally unexpected that he comes close to condemning the instructor for her intrusiveness:

B: I think what she's trying to prove with her comments is that just tells me that I'm off the track ... I'm not explaining my subject, I'm not explaining what I want to say and she's really stressing on that ... She doesn't care what I'm writing about or what I'm doing unless she sees her own topics and format in my paper.

B is thus trapped in a dilemma. The more he resists experimenting with the alternatives offered, the lower his chances of making a breakthrough, and the more he practices his own way of doing things, the more he shuts himself away from the conventional expectations of readers of expository prose.

Student C, a graduate student from the People's Republic of China, had been in the United States about 15 months at the time of interview. The discussion with $\mathrm{C}$ revealed that he saw the teacher's role as providing assistance in areas such as grammar and structure, but not in other areas such as content or subject matter:

$\mathrm{C}$ : Ah ... my feeling is that, ah, because what I write in this kind of thing, the content is more, you know, the content is more specially with my subject ... I think probably she doesn't understand you know what ... most of the content, so I think probably the important thing for her is that give us some, you know, comments on the structures and the grammars, something like that.

In the excerpt that follows, $\mathrm{C}$ expresses self-confidence in his own ability to make content decisions, and doubt about his teacher's:

I: She's asking you for more clarification here (referring to C's paper).

C: I think that, you know, in some areas she wanted the most basic thing you know ... something. I don't think ... this is very necessary for this paper, for this paper is just the reason for how the acid rain is formed. 
I: You are saying this title should be the clue, and you are going to write on the formation of acid rain?

C: Yeah.

I: Not where it is formed?

C: Yeah you can say that in some area, you know, I give some place why this place, you know, there are acid rain ... I just give the general idea and how this acid rain are formed ... I just ...

I: So what you are saying is that you don't actually agree with this comment?

C: Yeah.

Unlike the majority of the students interviewed, $C$ tended to be cautious about the benefits of rewriting. He conceded that if a student has simply scribbled something down, then that student may reasonably be asked to try again. However, if a student has expended much energy, then there is little point in rewriting. As he asseverates: "If I am asked to rewrite I will be very absent, you know". Like the typical Resistor in the questionnaire, $\mathrm{C}$ associates rewriting with failure and punishment, equating it with surface-level correction.

Like B, C sees little place in his world for rhetoric. On the one hand, he sees content as his responsibility and form, on the other, as a shared responsibility, but he does not preceive that the relating of the two via a set of rhetorical frameworks could help him improve his writing, both within his writing class and in his professional world.

\section{DISCUSSION}

The concerns that motivated this study are, we believe, widely shared by ESL writing instructors who reflect upon what they do in teaching writing. We want to believe that teacher feedback has a useful role to play in developing the skills of the apprentice writer yet personal experience and the drift of current research combine to show that teacher feedback "as currently constituted and realized may have more limited impact on the learners than the teachers would desire" (Cohen, forthcoming). In this paper we have suggested that a possible first step is to develop a typology of behaviors that characterizes student attitudes to teacher feedback, and we have reported our preliminary attempts to do this. Our study, we realize, has its limitations. The questionnaire sample size is small and drawn from a single institution. In the case of the eight students selected for subsequent interview, we have little idea of their past writing class experiences both in their native land and at other American institutions - factors of presumed importance (Mohan and Lo, 1985). The criteria for category assignment are not as operationally defined as we would like, and we continue to have doubts about the appropriacy of the Receptor-Resistor nomenclature. Moreover, we have yet to observe how students behave after having received a teacher-marked assignment.

Despite these shortcomings, the study does raise a number of issues relevant to college-level ESL writing instruction. First, it shows the variety of student attitudes to teacher feedback that can be expected in a multilingual ESL writing class at any set proficiency level (even' if we did not establish any correlations between response type and linguistic/cultural background). 
More relevant perhaps is the evidence of different student behaviour across the four ESL classes that we investigated. As students move away from classes where English is practiced for the sake of language learning (i.e. courses at the English Language Institute) to those in which language is seen as subservient to another discipline (i.e. Linguistics 340, Humanities 610), the more restricted the role they generally assign to the English instructor. Most strikingly, the students most advanced in their subjects tended to perceive the language instructor as a person skilled merely in the grammar of the target language and its explication but not skilled in its principles of rhetorical organization. At present, however, the reasons for this shift are not clear to us. Possible elements are increasing constraints on time and distance from direct language learning, increasing intellectual maturity and self-confidence, and the failure of writing instructors to show sensitivity to the conventions and genres of specific fields.

As seen in our analysis, the majority of our respondents, $87 \%$ (Receptors and Semi-resistors), appreciate substantive comments that allow them to rethink a piece of writing, yet these very students also expect the instructor to correct all their surface errors. If this attitude is indicative of ESL students in general, then, ESL writing instructors are faced with a dilemma. If they do not surface-correct but respond to a writer's meaning, their credibility among their students can be impaired. Clearly, teachers must intervene and change student attitudes; one way for teachers to change their students is by sharing with them the research in writing. Thus they could possibly vindicate their methods and reputation.

The negative attitude expressed by our non-receptive majority toward revision parallels that of many Ll writing students and reflects a limited approach to revision. As Flowers et al. (1986) point out, revision is often perceived differently by $\mathrm{Ll}$ teachers and students, experienced and inexperienced writers. Whereas teachers tend to view it as a generative process whereby meaning is reassessed and text is reshaped, students tend to view it as the correction of surface-level errors. Such a narrow attitude toward rewriting, which could be widespread among L2 students as well, can only hinder their development as L2 writers. Here, then, is another area in which L2 teachers can intervene to educate their students as to what writing can entail for the experienced writer.

The final issue is a most crucial one. As yet we have little hard evidence of any relationship between the type of student respondent and the proficiency level in ESL writing. We do not yet know whether Receptors and Semi-resistors are better writers than Resistors and, if they are, whether it is attributable to their acceptance of substantive and explicit feedback on their writing. We suspect that Resistors in particular are at greater risk than other groups; indeed, students $\mathrm{B}$ and $\mathrm{C}$ manifested attitudes in their interviews that revealed they had rejected advice that could help them improve their writing. Not until this uncertainty is diminished will we be able to help students respond more effectively to teacher feedback on their writing.

Patricia Radecki is a doctoral candidate and Teaching Assistant in the English Department at the University of Michigan. John Swales is Director of the English Language Institute and Professor of Linguistics at the University of Michigan. He is co-editor of the English for Specific Purposes journal; his Episodes in ESP was published by Pergamon Press in 1985. 


\section{NOTES}

$'$ In an analysis of the responses of thirty-five experienced teachers on three student papers, Sommers (1982) discovered that although her subjects intended to facilitate revision, their feedback thwarted their intentions. By positing comments that addressed usage errors next to comments calling for text alteration or expansion, the teachers communicated a conflicting message: that the text was fixed yet also in a state of flux. Furthermore, whether addressing meaning or technical aspects of a text, the instructors' comments were so vague and prescriptive that they could be easily applied to other texts.

${ }^{2}$ In each of those various studies, other forms of treatment (such as no correction) resulted in greater or equal improvement in grammatical accuracy as evidenced in post-tests or longitudinal analysis of writing. Robb et al. in particular, attribute the improvement which occurred across all the feedback groups in their study to the practice of writing itself. Their conclusions corroborate the views of many Ll composition theorists such as Knoblauch and Brannon (1984), who maintain that "composing is a competence which develops through use, not a system of skills to be serially introduced ... and then practiced" ( $p .104$ ). Thus there appears to be an emerging consensus among certain L1 and L2 writing researchers that response to textual meaning is the best means of aiding students in reshaping their writing.

\section{REFERENCES}

BURKLAND, J. and GRIMM, N. (1984) Students` response to our response. Paper presented at the Conference on College Composition and Communication, New York City, 1984.

COHEN, A. (forthcoming) The Processing of Feedback on Student Papers. In Wenden, A.L. and Rubin, J. (eds), Research on Learner Strategies. Prentice-Hall.

FAIGLEY, L. and WITTE, S. (1981) Analyzing revision. College Composition and Communication 32, $400-414$.

FLOWER, L. et al. (1986) Detection, diganosis, and the strategies of revision. College Composition and Communication $37,16-55$.

HENDRICKSON, J. M. (1976) The effects of error correction treatments upon adequate and accurate communication in the written compositions of adult learners of English as a second language. Unpublished dissertation, Ohio State University.

HENDRICKSON, J. M. (1977) Error analysis and selective correction in the adult ESL classroom: an experiment. ERIC ED 135260.

KNOBLAUCH, C. H. and BRANNON, L. (1984) Rhetorical Traditions and the Teaching of Writing. Upper Montclair. NJ: Boynton/Cook.

LALANDE, J. F. II (1982) Reducing composition errors: an experiment. The Modern Language Journal 66, 140 - 149 LYNCH, C. and KLEMENS, P. (1978) Evaluating our evaluations. College English 40, 166-180.

MOHAN, B. A. and AN-YEUNG LO, W. (1985) Academic writing and Chinese students: transfer and developmental factors. TESOL Quarterly 19, 515-534.

REED, W. M. and BURTON, J. K. (1981) Effective and ineffective evaluation of essays: perceptions of college freshmen. ERIC. ED 238022

ROBB, T. et al. (1986) Salience of feedback on error and its effect on EFL writing quality. TESOL Quarterly 20. $83-93$. SCHWARTZ, M. (1984) Responses to writing: a college-wide perspective. College English 46, 55-62.

SEMKE, H. D. (1984) Effects of the Red Pen. Foreign Language Annals 17, 195-202.

SIEGEL, M. E. A. (1982) Responses to student writing from new composition faculty. College Composition and Communication 33, 302-309.

SOMMERS, N. (1982) Responding to student writing. College Composition and Communication 33, $148-156$.

ZAMEL, V. (1985) Responding to student writing. TESOL Quarterly 19, 79-101.

ZIV. N. D. (1984) The effect of teacher comments on the writing of four college freshmen. In Beach. R. and Bridwell, L. S. (eds), New Directions in Composition Research. New York: Guilford. 